\title{
Short Communication: Canola Meal as a Substitute for Cottonseed Meal in Diet of Midlactation Holsteins
}

\author{
S. M. Maesoomi, ${ }^{*}$ G. R. Ghorbani, ${ }^{,}$M. Alikhani, ${ }^{*}$ and A. Nikkhaht ${ }^{1}$ \\ *Department of Animal Science, Isfahan University of Technology, Isfahan 84156, Iran \\ †Department of Animal Science, University of Manitoba, Winnipeg, MB, Canada R3T 2N2
}

\begin{abstract}
The growing demand by humans for monounsaturated vegetable oils has provided canola meal (CM) for use in dairy diets because it possesses an excellent nitrogen profile for rumen microbes. Six midlactation cows were used in a replicated $3 \times 3$ Latin square design with 3 periods of $20 \mathrm{~d}$ each. Treatments included diets with 1) CM, 2) $50 \% \mathrm{CM}+50 \%$ cottonseed meal (CSM), and 3) CSM. Total crude protein (CP), nonprotein nitrogen, and rapidly degradable true protein (\% of $\mathrm{CP})$ were greater in CM than in CSM. The neutral and acid detergent fibers, slowly degradable true protein, and unavailable CP were lower in CM than in CSM. Daily feeding of $3.4 \mathrm{~kg}$ of CM instead of $5.6 \mathrm{~kg}$ of CSM enhanced milk percentage of protein and SNF, and improved total tract digestibility of dry matter and CP. Therefore, CM offers an economical substitute for CSM in midlactation diets when commercial access, cost, and quality of CSM are variable.
\end{abstract}

Key words: canola meal, cottonseed meal, protein fraction, midlactation cow

Cottonseed meal (CSM) is used in dairy diets because of its lower price, limited use in nonruminant diets, and greater escape protein when compared with soybean meal (Coppock et al., 1987). However, limited access to CSM superimposed on its low Lys and Met concentrations and variable gossypol content appear to limit its dietary use for lactating cows (Coppock et al., 1987).

In view of the progressive human demand for vegetable oils high in monounsaturated fat and low in ratio of n-6 to n-3 polyunsaturated fatty acids, canola cultivars with largely reduced levels of glucosinolates $(\mathbf{G T})$ have been developed. This progress in plant breeding has concomitantly served the dairy diets with canola meal (CM; Sanchez and Claypool, 1983). Meanwhile, the high ruminal degradability of $\mathrm{CP}$ has led researchers

Received July 5, 2005.

Accepted November 15, 2005.

${ }^{1}$ Corresponding author: umnikkha@cc.umanitoba.ca to process CM (Khorasani et al., 1993). The processing of CM aims to minimize the ruminal surplus of soluble $\mathrm{N}$ and optimize the small intestinal supply of the most limiting AA for milk synthesis (i.e., Met, Lys, His, and Phe; Schingoethe, 1996). The benefits of increased RUP due to processing CM seem, however, to be offset by conducting the costly, standardized processing techniques. Besides, CM already contains a RUP residue whose strata of AA are remarkably close to that of milk protein (Piepenbrink and Schingoethe, 1998). More importantly, CM possesses an excellent RDP profile that may stimulate microbial growth in the rumen (Piepenbrink and Schingoethe, 1998). Such efficient provision of AA and peptides, readily incorporated into microbial mass (Bach et al., 2005), becomes more prominent in the light of recent timely emphases (Santos et al., 1998; Bach et al., 2005) on significance of RDP for efficient microbial metabolism and milk synthesis.

In the current animal feed market in Iran, CM is similar in price to CSM (185 vs. 195 toman/kg; US $\$ 1=$ 916 toman), but is much higher in CP (44 vs. 29\%). In other words, on average, CM is cheaper than CSM by about 5 and $60 \%$ per $\mathrm{kg}$ of $\mathrm{DM}$ and $\mathrm{CP}$, respectively. The antinutritive factors in CSM and the adverse environmental impacts of feeding high amounts of unavailable $\mathrm{N}$ are additional concerns that justify introducing a commercial alternative for CSM. Therefore, we designed this study to 1) address the significance of using more economical protein sources (e.g., CM) by the dairy industry in Iran, and 2) underline the importance of dietary RDP in the form of CM for lactating cows. We hypothesized that full dietary substitution of highly degradable $\mathrm{CP}$ of $\mathrm{CM}$ for the less degradable $\mathrm{CP}$ of CSM maintains productivity without affecting DMI, nutrient digestibility, or circulating thyronines and albumin. We fractionated $\mathrm{CP}$ of $\mathrm{CM}$ and $\mathrm{CSM}$, and assessed the effect of dietary substitution of CM for CSM on performance of midlactation cows.

Six (3 primiparous and 3 multiparous) Holstein cows $(600 \pm 50 \mathrm{~kg}$ of BW), $120 \pm 4$ DIM with $34 \pm 2 \mathrm{~kg} / \mathrm{d}$ (mean $\pm \mathrm{SE}$ ) initial milk yield were used in a replicated 3 $\times 3$ Latin square design. Cows were housed in individual stalls $(4 \times 4 \mathrm{~m})$ in a roofed area at the Dairy Facilities of Lavark Research Station (Isfahan University of Tech- 
Table 1. Ingredients and nutrient composition of the diets (DM basis)

\begin{tabular}{|c|c|c|c|}
\hline \multirow[b]{2}{*}{ Item } & \multicolumn{3}{|c|}{ Dietary treatment ${ }^{1}$} \\
\hline & CM & $\mathrm{CC}$ & CSM \\
\hline Alfalfa hay & 49.6 & 46.2 & 39.5 \\
\hline Corn grain & 13.7 & 13.7 & 13.8 \\
\hline Barley grain & 16.1 & 16.2 & 16.3 \\
\hline Canola meal & 14.3 & 9.0 & - \\
\hline Cottonseed meal & - & 9.0 & 23.6 \\
\hline Whole linted cottonseed & 2.4 & 2.4 & 2.4 \\
\hline Wheat bran & 2.4 & 2.0 & 2.9 \\
\hline Sodium bicarbonate & 0.9 & 0.9 & 0.9 \\
\hline Vitamin and mineral supplement ${ }^{2}$ & 0.6 & 0.6 & 0.6 \\
\hline $\mathrm{NE}_{\mathrm{L}}(\mathrm{Mcal} / \mathrm{kg})^{3}$ & 1.50 & 1.51 & 1.52 \\
\hline $\mathrm{CP}, \%$ & 17.2 & 17.3 & 17.2 \\
\hline $\mathrm{RDP},{ }^{3} \%$ & 12.4 & 12 & 11.4 \\
\hline RUP, ${ }^{3} \%$ & 4.8 & 5.3 & 5.8 \\
\hline $\mathrm{NDF}, \%$ & 36.4 & 37.5 & 37.8 \\
\hline $\mathrm{ADF}, \%$ & 21.6 & 22.7 & 23.2 \\
\hline $\mathrm{NFC},{ }^{4} \%$ & 37.8 & 37.0 & 36.1 \\
\hline $\mathrm{EE}, \%$ & 3.0 & 3.1 & 3.3 \\
\hline $\mathrm{Ca}, \%$ & 1.0 & 0.9 & 0.8 \\
\hline $\mathrm{P}, \%$ & 0.4 & 0.5 & 0.5 \\
\hline $\mathrm{DCAD},{ }^{5} \mathrm{mEq} / \mathrm{kg}$ & 282 & 290 & 303 \\
\hline
\end{tabular}

${ }^{1} \mathrm{CM}=$ Canola meal $\mathrm{CC}=50 \%$ canola meal $+50 \%$ cottonseed meal; $\mathrm{CSM}=$ cottonseed meal.

${ }^{2}$ Contained (per kilogram): $19.6 \% \mathrm{Ca}, 9.6 \% \mathrm{P}, 7.1 \% \mathrm{Na}, 1.9 \% \mathrm{Mg}$, $0.3 \% \mathrm{Fe}, 0.03 \% \mathrm{Cu}, 0.2 \% \mathrm{Mn}, 0.3 \% \mathrm{Zn}, 100 \mathrm{ppm} \mathrm{Co}, 100 \mathrm{ppm} \mathrm{I}, 0.1$ ppm Se, $50 \times 10^{5} \mathrm{IU}$ of vitamin A, $10 \times 10^{5} \mathrm{IU}$ of vitamin $\mathrm{D}$, and 0.1 $\mathrm{g}$ of vitamin $\mathrm{E}$.

${ }^{3}$ Calculated from NRC (2001).

${ }^{4} \mathrm{NFC}=100-(\mathrm{NDF} \%+\mathrm{CP} \%+$ ether extract $\%+\operatorname{ash} \%)$.

${ }^{5} \mathrm{DCAD}=\left(\mathrm{Na}^{+}+\mathrm{K}^{+}\right)-\left(\mathrm{Cl}^{-}+\mathrm{S}^{-}\right)$.

nology, Iran) from July to September 2004. The experiment consisted of three 20 -d periods. The first $15 \mathrm{~d}$ of each period were for acclimation to the experimental conditions, and the last $5 \mathrm{~d}$ for data collection. Cows were allowed $2 \mathrm{~h}$ of outdoor exercise every morning for the entire experiment.

Treatments included the diets containing: 1) CM;2) $50 \%$ CM + 50\% CSM; or 3) CSM (Table 1). Diets were formulated (NRC, 2001) to contain equal levels of $\mathrm{NE}_{\mathrm{L}}$, $\mathrm{CP}$, and NDF (Table 1). Cows were offered TMR twice daily at 0800 and $1400 \mathrm{~h}$ at rates to allow for 5 to $10 \%$ orts. Fecal samples were obtained from the rectum, and urine was sampled by manual stimulation of the vulva at $1100 \mathrm{~h}$ every day of the collection period. Acid insoluble ash was used as an internal marker to determine the apparent total tract digestibility of nutrients. The $\mathrm{CP}$ of CM and CSM was fractionated (Table 2) according to the Cornell Net Carbohydrate and Protein System (Sniffen et al., 1992), as described by Licitra et al. (1996). On the last day of each period, $10 \mathrm{~mL}$ of blood was collected via jugular vein. The plasma thyroid hormones (triiodothyronine and thyroxine) were measured by standard radioimmunoassay using commercial kits (Kavoshyar Kit, clinical diagnostic, Isfahan, Iran). The serum was assayed for albumin using cellulose acetate electrophoresis. Cows were milked thrice daily in the milking parlor at 0500,1300 , and $2100 \mathrm{~h}$. Milk samples were analyzed (AOAC, 1990) for fat, protein, SNF, lactose, and TS using a Milk-O-Scan (134 BN Foss Electric, Hillerłd, Denmark).

Data were analyzed as a linear mixed model with PROC MIXED of SAS (SAS Institute, 1999). The initial model included the fixed effects of treatment, period, parity, treatment $\times$ parity, and random effect of cow nested within parity. Because of insignificance $(P>$ $0.30)$, parity and its interaction with treatment were excluded from the model. Period was modeled as a repeated factor with first-order autoregressive [AR (1)] covariance structure to account for the correlation of repeated measures on the same subject (Tempelman, 2004).

The CM contained significantly less $(P<0.01) \mathrm{NDF}$ and ADF than did CSM (Table 2). The CM was, however, higher in CP but lower in ether extract than was CSM $(P<0.01)$. The fractionation of $\mathrm{CP}$ revealed that NPN (fraction A) and rapidly degradable true protein (fraction $\mathrm{B}_{1}$ ) were greater $(P<0.01)$ in CM than in CSM. However, the slowly degradable (escape) true protein (fraction $\mathrm{B}_{3}$ ), total true protein, and unavailable $\mathrm{N}$ (fraction $\mathrm{C}$ ) were lower $(P<0.01)$ in CM than in CSM (Table 2). Daily DMI, feed efficiency, actual milk yield, milk fat content and yield, and the yield of $4 \%$ FCM were not altered by treatments (Table 3). Milk percentage of protein and SNF were increased by dietary substitution of CM for CSM (Table 3).

Complete substitution of dietary $\mathrm{CP}$ of $\mathrm{CM}$ for that of CSM in midlactation diet improved the apparent total tract digestibility of dietary DM $(P=0.01), \mathrm{CP}(P$ $<0.01)$, and $\mathrm{OM}(P=0.07$; Table 4$)$. The concentrations of albumin and thyronines [triiodothyronine $\left(\mathrm{T}_{3}\right)$ and thyroxine $\left(\mathrm{T}_{4}\right)$ ] in circulating blood were not impacted by treatments (Table 4 ).

The significantly different $\mathrm{CP}$ content of $\mathrm{CM}$ and CSM (Table 2) was in disagreement with Sniffen et al. (1992) who reported comparable CP contents for CM (42.3\%) and CSM (44.8\%). The discrepancy between the 2 studies could be explained by the lower NDF and ADF in CM than in CSM in our study. The CSM used in the current trial was higher in fiber, but lower in NPN and CP compared with that used in other studies (Sniffen et al., 1992; Licitra et al., 1996). Such interstudy differences in nutrient composition of CSM could be attributed to the variety of the cottonseeds produced under specific agronomic conditions. The processing conditions (e.g., temperature, pressure, and chemicals used) during the extraction of oil from oilseeds could also affect nutrient composition of protein meals. Moreover, the high levels of $\mathrm{N}$ associated with $\mathrm{ADF}$ in $\mathrm{CSM}$ of the present study should have, at least partly, contributed 
Table 2. Crude protein fractions and fibers of canola and cottonseed meals (DM\%) ${ }^{1}$

\begin{tabular}{|c|c|c|c|}
\hline Item & $\begin{array}{l}\text { Canola } \\
\text { meal }\end{array}$ & $\begin{array}{l}\text { Cottonseed } \\
\text { meal }\end{array}$ & $P$-value \\
\hline $\mathrm{DM}, \%$ & 94.9 & 94.2 & NS \\
\hline $\mathrm{CP}, \%$ & 44.0 & 29.0 & $* * *$ \\
\hline \multicolumn{4}{|l|}{$\mathrm{CP}$ fractions, $\%$ of total $\mathrm{CP}$} \\
\hline NPN (fraction A) & 13.9 & 5.2 & $* * *$ \\
\hline Rapidly degradable true protein (fraction $\mathrm{B}_{1}$ ) & 27.5 & 3.9 & $* * *$ \\
\hline Moderately degradable true protein (fraction $\mathrm{B}_{2}$ ) & 47.4 & 43.5 & NS \\
\hline Slowly degradable true protein ${ }^{2}$ (fraction $\mathrm{B}_{3}$ ) & 8.6 & 36.6 & $* * *$ \\
\hline Unavailable protein $^{3}$ (fraction C) & 2.6 & 10.8 & $* * *$ \\
\hline Total true protein & 86.1 & 94.8 & $* *$ \\
\hline $\mathrm{NDF}, \%$ & 27.5 & 50.0 & $* * *$ \\
\hline $\mathrm{ADF}, \%$ & 20.8 & 36.5 & $* * *$ \\
\hline Ether extract, \% & 2.4 & 6.1 & $* *$ \\
\hline Ash, \% & 6.2 & 4.0 & * \\
\hline
\end{tabular}

${ }^{1}$ Canola meal contained $6.62 \mu \mathrm{mol} / \mathrm{g}$ of glucosinolates. The CP was fractionated according to Licitra et al. (1996) and based on Cornell Net Carbohydrate and Protein System (Sniffen et al., 1992).

${ }^{2}$ Neutral detergent insoluble protein - unavailable CP.

${ }^{3}$ Acid detergent insoluble protein.

$* P<0.05 ; * * P<0.01 ; * * * P<0.001 ; \mathrm{NS}=P>0.20$.

to the higher levels of fibers in CSM compared with CM (Table 2). The high fiber and its associated $\mathrm{N}$ as well as the low CP of CSM were indeed influential in designing the current experiment. This was to characterize the economical benefits of using CM with greater CP than more costly CSM with variable quality.

As expected, CM provided a greater amount of rapidly degradable protein than did CSM, which agreed with Sniffen et al. (1992). The $\mathrm{B}_{1}$ fraction of CP represents albumins and globulins that are readily fermentable and required for the continuous microbial growth in the rumen (Sniffen et al., 1992). Thus, the dietary sub- stitution of CM for CSM in the present study may have elevated the ruminal availability of $\mathrm{N}$. The $\mathrm{C}$ fraction, which is neither available in the rumen nor in the small intestine, was lower $(P<0.05)$ in CM than in CSM. The greater apparent total tract digestibility of nutrients in cows fed CM than in cows fed CSM could, therefore, be explained by the lower content of unavailable $\mathrm{N}$ and $\mathrm{ADF}$ in CM (Tables 1 and 4). The low unavailable CP is expected to reduce the fecal excretion of $\mathrm{N}$, thereby increasing CP digestibility. Additionally, the gossypol in CSM might bind dietary Lys (Reiser and Fu, 1962), rendering it unavailable in the small intestine.

Table 3. Dry matter intake, feed efficiency, and milk yield and composition of cows fed the dietary treatments

\begin{tabular}{|c|c|c|c|c|c|}
\hline \multirow[b]{2}{*}{ Item } & \multicolumn{3}{|c|}{ Treatment $^{1}$} & \multirow[b]{2}{*}{$\mathrm{SE}^{2}$} & \multirow{2}{*}{$\begin{array}{l}\text { Treatment } \\
\text { effect, } P\end{array}$} \\
\hline & $\mathrm{CM}$ & $\mathrm{CC}$ & CSM & & \\
\hline DMI, kg/d & 23.4 & 23.8 & 23.9 & 0.48 & 0.55 \\
\hline Actual milk yield, $\mathrm{kg} / \mathrm{d}$ & 28.0 & 28.5 & 27.0 & 1.1 & 0.55 \\
\hline $4 \%$ FCM, kg/d & 24.3 & 25.6 & 24.8 & 1.0 & 0.48 \\
\hline FCM:DMI & 1.04 & 1.08 & 1.05 & 0.03 & 0.33 \\
\hline \multicolumn{6}{|l|}{ Milk components } \\
\hline Fat, $\%$ & 3.15 & 3.35 & 3.44 & 0.16 & 0.26 \\
\hline Fat yield, kg/d & 0.87 & 0.95 & 0.93 & 0.04 & 0.25 \\
\hline Protein, $\%$ & $3.08^{\mathrm{a}}$ & $3.02^{\mathrm{b}}$ & $2.98^{\mathrm{b}}$ & 0.02 & 0.01 \\
\hline Protein yield, kg/d & 0.86 & 0.86 & 0.81 & 0.04 & 0.40 \\
\hline Milk protein efficiency ${ }^{3}$ & 213 & 209 & 198 & 5.8 & 0.23 \\
\hline Lactose, \% & 5.41 & 5.36 & 5.39 & 0.02 & 0.23 \\
\hline Lactose yield, $\mathrm{kg} / \mathrm{d}$ & 1.52 & 1.53 & 1.46 & 0.07 & 0.57 \\
\hline SNF, \% & $8.49^{\mathrm{a}}$ & $8.38^{b}$ & $8.38^{\mathrm{b}}$ & 0.03 & 0.01 \\
\hline SNF yield, $\mathrm{kg} / \mathrm{d}$ & 2.37 & 2.39 & 2.27 & 0.10 & 0.52 \\
\hline TS, $\%$ & 12.4 & 12.5 & 12.6 & 0.14 & 0.66 \\
\hline TS yield, kg/d & 3.47 & 3.56 & 3.41 & 0.11 & 0.66 \\
\hline
\end{tabular}

${ }^{\mathrm{a}, \mathrm{b}}$ Values with different superscripts in the same row differ significantly $(P<0.05)$.

${ }^{1} \mathrm{CM}=$ Canola meal $\mathrm{CC}=50 \%$ canola meal $+50 \%$ cottonseed meal CSM $=$ cottonseed meal.

${ }^{2} \mathrm{SE}=$ Standard error of difference between least square means.

${ }^{3}$ The ratio of milk protein yield $(\mathrm{g} / \mathrm{d})$ to daily protein intake $(\mathrm{kg} / \mathrm{d})$. 
Table 4. Apparent total tract digestibility of nutrients and circulating thyronines ${ }^{1}$ and albumin in cows fed the dietary treatments

\begin{tabular}{|c|c|c|c|c|c|}
\hline \multirow[b]{2}{*}{ Item } & \multicolumn{3}{|c|}{ Treatment $^{2}$} & \multirow[b]{2}{*}{$\mathrm{SE}^{3}$} & \multirow{2}{*}{$\begin{array}{l}\text { Treatment } \\
\text { effect, } P\end{array}$} \\
\hline & $\mathrm{CM}$ & $\mathrm{CC}$ & CSM & & \\
\hline \multicolumn{6}{|c|}{ Apparent total tract digestibility } \\
\hline DM, \% & $75.7^{\mathrm{a}}$ & $70.7^{\mathrm{b}}$ & $70.4^{b}$ & 1.2 & 0.01 \\
\hline $\mathrm{OM}, \%$ & 77.0 & 72.5 & 72.8 & 1.7 & 0.07 \\
\hline $\mathrm{CP} \%$ & $78.3^{\mathrm{a}}$ & $74.5^{\mathrm{b}}$ & $73.1^{\mathrm{b}}$ & 1.4 & 0.009 \\
\hline $\mathrm{NDF}, \%$ & 64.3 & 57.5 & 58.7 & 2.3 & 0.20 \\
\hline $\mathrm{ADF}, \%$ & 50.7 & 47.3 & 45.7 & 2.1 & 0.30 \\
\hline Plasma $_{3}, \mathrm{ng} / \mathrm{mL}$ & 1.59 & 1.54 & 1.60 & 0.05 & 0.42 \\
\hline Plasma $\mathrm{T}_{4}, \mathrm{ng} / \mathrm{mL}$ & 28.89 & 29.25 & 29.89 & 1.87 & 0.90 \\
\hline Serum albumin, $\mathrm{g} / \mathrm{dL}$ & 33.82 & 33.85 & 34.03 & 0.72 & 0.65 \\
\hline
\end{tabular}

${ }^{a, b}$ Values with different superscripts in the same row differ significantly $(P<0.05)$.

${ }^{1}$ Triiodothyronine $\left(\mathrm{T}_{3}\right)$ and thyroxine $\left(\mathrm{T}_{4}\right)$.

${ }^{2} \mathrm{CM}=$ Canola meal; $\mathrm{CC}=50 \%$ canola meal $+50 \%$ cottonseed meal CSM $=$ cottonseed meal.

${ }^{3} \mathrm{SE}=$ Standard error of difference between least square means.

The equal DMI of cows fed CM and CSM was in accord with DePeters and Bath (1986) who found no effects of using CM as $13 \%$ of dietary DM on DMI. The $\mathrm{CM}$ used in the present study contained $6.62 \mu \mathrm{mol} / \mathrm{g}$ of GT, so the theoretical maximum amount of GT ingested by the cows was about $23 \mathrm{mmol} / \mathrm{d}$. A daily ingestion of $47 \mathrm{mmol}$ of GT from CM did not decrease DMI of cows (Laarveld et al., 1981). Therefore, the low level of GT in CM of our study could have not compromised DMI of cows in midlactation.

The similar yields of milk and its components for cows across different treatments supported the similar DMI, and were in agreement with previous studies (Sanchez and Claypool, 1983; DePeters and Bath, 1986). Of note, cows in the present study consumed approximately $3.4 \mathrm{~kg} / \mathrm{d} \mathrm{CM}$, which was markedly greater than $2.44 \mathrm{~kg} / \mathrm{d}$ reported by DePeters and Bath (1986). The more economically significant effect was that cows in our study consumed as much as $5.6 \mathrm{~kg}$ of CSM $(5.6 \times 195$ toman $=1,092$ toman $)$ to obtain the same productivity as cows fed only $3.4 \mathrm{~kg}$ of $\mathrm{CM}(3.4 \times$ 185 toman $=629$ toman). In addition, the lower dietary inclusion rate of $\mathrm{CM}$ allowed for greater use of roughage that was on average $20 \%$ cheaper than CM and CSM (150 vs. 185 and 195 toman/kg). The greater dietary inclusion of roughage would, in turn, minimize feeding costs further where protein meals are more expensive and less available than forages (e.g., alfalfa), as is currently the case for the animal industry in Iran. Also, a more flexible dietary accommodation of roughages would mean a less compromised rumen environment.

The feed and milk protein efficiencies were similar across treatments (Table 3). Thus, it could be postulated that microbial protein synthesis in cows fed CM was complementary to dietary RUP in supplying the essential AA for milk protein synthesis. In a 12 -yr review of the studies on the effect of RUP on productivity of dairy cows, Santos et al. (1998) concluded that overemphasis on RUP with no independent consideration of RDP may unfavorably influence ruminal N metabolism. Given its excellent AA profile, the highly degradable $\mathrm{CP}$ of $\mathrm{CM}$ (Table 2) may have stimulated ample microbial growth in the rumen. The greater milk protein content of cows on CM (Table 3) supports the above speculation and concurs with Piepenbrink and Schingoethe (1998), who underlined the remarkable balance of AA in CM. Owing to the high degradability of CP and excellent AA profile of CM, Piepenbrink and Schingoethe (1998) suggested that RDP from CM favors microbial protein synthesis in the rumen. The enriched milk SNF due to feeding CM instead of CSM could then be explained by the increased milk protein.

Similar levels of plasma thyronines and serum albumin among treatments (Table 4) concur with the results of Sanchez and Claypool (1983) who observed no longterm effects of feeding CM on these criteria. The equal levels of serum albumin for cows fed CM and CSM may imply that liver production of albumin was not compromised by feeding CM.

In conclusion, feeding midlactation cows the highly ruminally degradable $\mathrm{CM}$ instead of the less degradable CSM increased milk percentage of protein and SNF, and improved the apparent total tract digestibility of DM and CP. More appreciably, these improvements were obtained while the daily intake of CM $(3.4 \mathrm{~kg} / \mathrm{d})$ was $65 \%$ lower than that of CSM $(5.6 \mathrm{~kg} / \mathrm{d})$. This allowed a $10 \%$ greater inclusion rate of forage (DM basis) in the diet containing CM. Continuous monitoring of glucosinolates in CM would be recommended if its long-term dietary use is anticipated. 


\section{ACKNOWLEDGMENTS}

We acknowledge the staff at Lavark Research Station (Isfahan University of Technology) for care of the animals, and Reza Khorasani (University of Alberta) for his critical review of the manuscript.

\section{REFERENCES}

AOAC. 1990. Official Methods of Analysis. 15th ed. Association of Official Analytical Chemists, Arlington, VA.

Bach, A., S. Calsamiglia, and M. D. Stern. 2005. Nitrogen metabolism in the rumen. J. Dairy Sci. 88(E. Suppl.):E9-E21.

Coppock, C. E., J. K. Lanham, and J. L. Horner. 1987. A review of the nutritive value and utilization of whole cottonseed, cottonseed meal and associated by-products by dairy cattle. Anim. Feed Sci. Technol. 18:89-129.

DePeters, E. J., and D. L. Bath. 1986. Canola meal versus cottonseed meal as the protein supplement in dairy diets. J. Dairy Sci. 69:148-154.

Khorasani, G. R., P. H. Robinson, and J. J. Kennelly. 1993. Effects of canola meal treated with acetic acid on rumen degradation and intestinal digestibility in lactating dairy cows. J. Dairy Sci. 76:1607-1616.

Laarveld, B., R. P. Brockman, and D. A. Christensen. 1981. The effects of Tower and Midas rapeseed meals on milk production and concentrations of goitrogens and iodide in milk. Can. J. Anim. Sci. 61:131-139.

Licitra, G., T. M. Hernandez, and P. J. Van Soest. 1996. Standardization of procedures for nitrogen fractionation of ruminant feeds. Anim. Sci. Feed Technol. 57:347-358.

NRC. 2001. Nutrient Requirements of Dairy Cattle. 7th rev. ed. National Acad. Sci., Washington, DC.

Piepenbrink, M. S., and D. J. Schingoethe. 1998. Ruminal degradation, amino acid composition, and estimated intestinal digestibilities of four protein supplements. J. Dairy Sci. 81:454-461.

Reiser, R., and H. C. Fu. 1962. The mechanism of gossypol detoxification by ruminant animals. J. Nutr. 76:215-218.

Sanchez, J. M., and D. W. Claypool. 1983. Canola meal as a protein supplement in dairy rations. J. Dairy Sci. 66:80-85.

Santos, F. A. P., J. E. P. Santos, C. B. Theurer, and J. T. Huber. 1998. Effects of rumen-undegradable protein on dairy cow performance: A 12-year literature review. J. Dairy Sci. 81:3182-3213.

SAS Institute. 1999. SAS User's Guide. Version 8 ed. SAS Institute Inc., Cary, NC.

Schingoethe, D. J. 1996. Dietary influence on protein level in milk and milk yield in dairy. Anim. Feed Sci. Technol. 60:181-190.

Sniffen, C. J., J. D. O'Connor, P. J. Van Soest, D. G. Fox, and J. B. Russell. 1992. A net carbohydrate and protein system for evaluating cattle diets: II. Carbohydrate and protein availability. J. Anim. Sci. 70:3562-3577.

Tempelman, R. J. 2004. Experimental design and statistical methods for classical and bioequivalence hypothesis testing with an application to dairy nutrition studies. J. Anim. Sci. 82(E. Suppl.):E162-E172. 